Вісник Національного університету “Львівська політехніка”. Серія "Проблеми економіки та управління"

T. 4, № 1, 2020

JEL Classification Code: M31

Grzegorz Biesok

University of Bielsko-Biala (Poland),

Department of Management

\title{
CUSTOMER SATISFACTION AND RETAILER IMAGE AS DRIVERS OF CUSTOMER LOYALTY: EVIDENCE FROM POLISH SUPERMARKETS
}

https://doi.org/10.23939/semi2020.01.135

(C) Biesok G., 2020

The paper presents results of research on customer loyalty drivers on retail market. It verifies the degree of impact of customer satisfaction and retailer image on customer loyalty. The paper uses primary survey data, multi-item scales and structural equations modelling (SEM).

The conceptual model used in the study combines 3 latent variables: retailer image, customer satisfaction and customer loyalty. Latent variables were equipped with a set of manifest variables, and they were measured in a survey. The paper assumes the following hypotheses: H1: there is a strong positive impact of retailer image on customer loyalty; H2: there is a strong positive impact of customer satisfaction on customer loyalty; H3: retailer image has a certain influence on customer satisfaction, as well.

The survey was focused on supermarkets from southern Poland and their clients. The questionnaires were distributed using snowballing method. In total the sample included 328 respondents. A given table provides the results of the survey with the elements and structure of the sample.

Reliability of the measurement model was evaluated with reliability coefficients: Cronbach's $\alpha$ and McDonald's $\omega$. All blocks of manifest variables showed sufficient internal consistency ( $\alpha$ and $\omega>0.7$ ) so they could be used to determine the model. Structural equation modelling confirmed all relationships in the model at a high significance level $(p<=0.001)$. Additionally the model fit reached sufficient level. In the result the study showed that retailer image and customer satisfaction have important influence on customer loyalty. An important finding is that customer satisfaction has two times bigger impact on loyalty than retailer image. This led into conclusion that retailers should focus on building customer satisfaction, as it is the main drive of loyalty. The conclusion is made about the understanding of customer needs and expectations and meeting them should be a priority for managers, because it translates into customer affection and adequate profitability in the long term. The author highlights, that future research should concentrate on the different types of loyalty and theirs drivers, because there relation are not sufficiently explained in the literature. In author's opinion, the relation between brand loyalty and loyalty to the retailer is also an interesting field of research.

In general, the article emphasizes the importance of scientific research of the relationships of buyers and retailers, that provide those services is very important in both 


\section{G. Biesok}

\section{theoretical and practical terms. This field of activity occupies one of the main areas of any country economy.}

Key words: consumer research, customer satisfaction, customer loyalty, supermarkets, retail.

\section{Statement of the problem}

Customer loyalty can be understood and defined differently, but it is certainly based on customer's strong and friendly relationship with a company (supplier or product). This relationship has not only an emotional nature, but also translates into specific customer behaviours or attitudes, among which Biesok and Wyród-Wróbel (2016) distinguish e.g.:

- making regular, recurring purchases,

- spreading positive information about product or company (word of mouth),

- positive attitude towards the product or company,

- resistance to activities of the competition,

- spontaneous product/ brand recall.

Literature broadly explains various models of customer loyalty. However, none of the presented theories is a dominating one. Drivers and outcomes of customer loyalty vary in different studies or different branches. Researches often indicates that customer satisfaction and the image of the store (brand) are the most important antecedents of customer loyalty. However, these results are not conclusive. That is why it is so important to study the relationships between these constructs in various economic and market realities, industries, and cultures.

\section{Analysis of recent research and publications}

Customer satisfaction and customer loyalty are one of the most important ideas in the marketing literature. They are a frequent subject of marketing and consumer research. Studies are carried out in various branches, various cultures and in various markets. On the retail area there is a lot of studies performed by numerous scholars, e.g. East et al. (2000), Koo (2003), Stone et al. (2004), Yang \& Peterson (2004), Chen \& Quester (2006), Turner \& Wilson (2006), Clottey et al (2008), Huddleston et. al (2009), Beneke et al. (2011), Nesset, Nervik \& Helgesen (2011), Zakaria et al. (2014), Ivanauskienė \& Volungènaitè (2014), Weerasiri, (2015), Kamran-Disfani et al. (2017), Biesok \& Wyród-Wróbel (2018) and many others.

Most of the scholars proves that customer satisfaction is the antecedents of customer loyalty. For example customer satisfaction in a retail industry was linked with loyalty by Weerasiri (2015). Mafini \& Dhurup (2015) showed that the level of store satisfaction among store customers is a reflection of the extent to which these customers are loyal to that store and store satisfaction is as a significant predictor of customer loyalty. Similarly Yang \& Peterson (2004) claim that customer loyalty can be generated through improving customer satisfaction and offering high product/service value.

However, the nature of this relationship is not definitely explained. Kamran-Disfani et al. (2017) show that customer satisfaction positively affects only attitudinal loyalty. According to them there is no direct relationship between satisfaction and behavioural loyalty and this kind of loyalty is supported by satisfaction indirectly.

Some literature suggests that a satisfied customer does not always become a loyal customer (Oliver, 1999). For example Miranda, Kónya \& Havrila (2005) found that the overall store satisfaction was not a significant variable in influencing store loyalty.

The second construct described in the paper is retailer image. Cornelius, Natter \& Faure (2010) consider it as the way in which a store is perceived by shoppers, and defined in shoppers' minds. Some researchers indicate that store image is among the most often accredited antecedents of satisfaction (e.g. Anderson \& Sullivan 1993). Beneke et al. (2011) claim that retailer image is a function of a number of 
attributes, specifically service levels, price perceptions and the variety of merchandise on offer. They conclude that customer satisfaction is necessary for a relationship to exist between both store image and loyalty, and between trust and loyalty. Customer satisfaction is the key area of focus in determining the loyalty of shoppers.

\section{Formulation of objectives}

The purpose of the paper is to verify the degree of impact of the customer satisfaction and retailer image on customer loyalty on a specific market. The research was focused on supermarkets from southern Poland and their clients.

As the literature review shows, these two factors are presented in research as the principal antecedents of the customer loyalty. Thus, the paper assumes the following hypotheses:

H1: There is a strong positive impact of retailer image on customer loyalty.

$\mathrm{H} 2$ : There is a strong positive impact of customer satisfaction on customer loyalty.

H3: Retailer image has a certain influence on customer satisfaction, as well.

Conceptual model used in the study is shown on the Fig. 1.

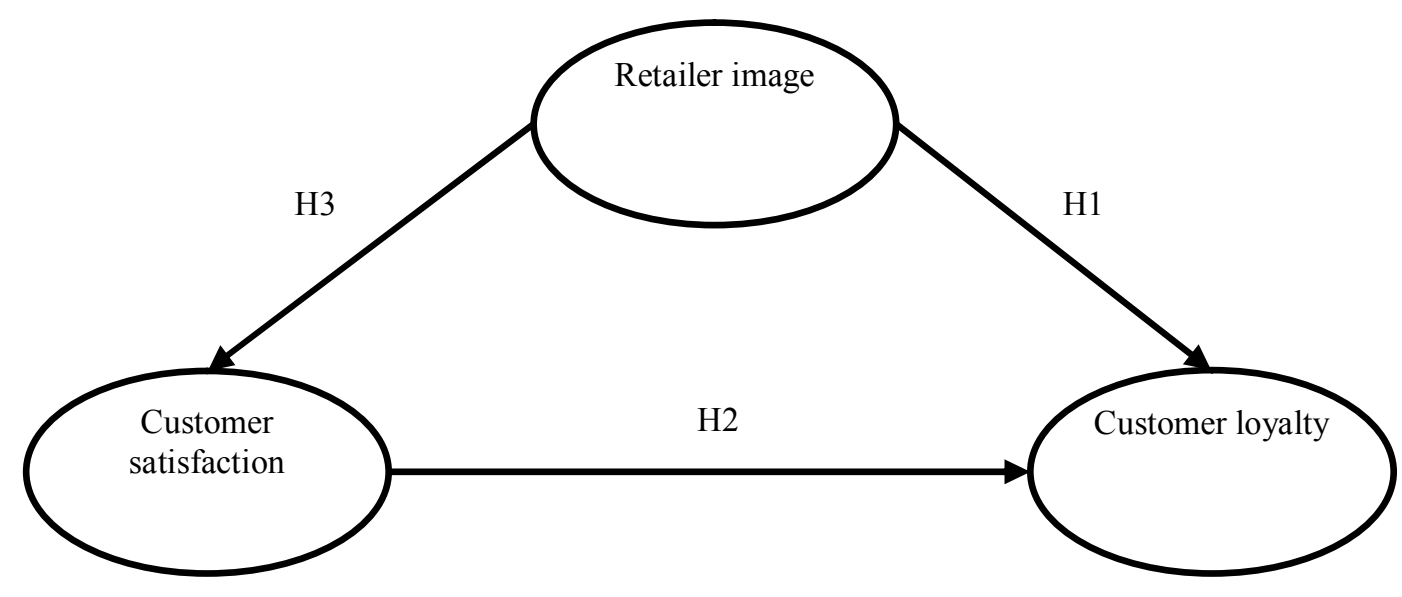

Fig. 1. Conceptual model used in the study

Source: own elaboration.

The paper uses primary survey data, multi-item scales and structural equations modelling (SEM).

\section{Presentation of the main material}

The conceptual model used in the study combines 3 latent variables. Every latent variable was equipped with a set of manifest variables. They are shown in table 1.

Manifest variables were measured in a survey with 5-point Likert's scale, from 1 - "I do not agree at all" to 5 - "I extremely agree". The questionnaires were distributed among supermarkets' clients in southern Poland, using snowballing method. After a control, 328 questionnaires were approved for further analysis. Table 2 shows the structure of the sample.

Reliability of the measurement model was evaluated with reliability coefficients: Cronbach's $\alpha$ and McDonald's $\omega$. All blocks of manifest variables showed sufficient internal consistency ( $\alpha$ and $\omega>0.7$ ) so they could be used to determine the model. Assumptions of the modelling are presented in Table 2. 


\section{G. Biesok}

Table 1

Variables used in the model

\begin{tabular}{|l|l|c|}
\hline \multicolumn{1}{|l|}{ Latent variable } & \multicolumn{1}{|c|}{ Manifest variables } & $\begin{array}{c}\text { Reliability } \\
\text { coefficients }\end{array}$ \\
\hline $\begin{array}{l}\text { Retailer image } \\
\text { IMG }\end{array}$ & $\begin{array}{l}\text { The supermarket has a positive image among customers } \\
\text { The supermarket is modern (innovative) } \\
\text { The supermarket is customer friendly } \\
\text { The supermarket provides its services well } \\
\text { The supermarket is trustworthy } \\
\text { The supermarket has a better reputation than supermarkets in the area }\end{array}$ & $\begin{array}{l}\alpha=0.848 \\
\omega=0.857\end{array}$ \\
\hline $\begin{array}{l}\text { Customer } \\
\text { SATisfaction }\end{array}$ & $\begin{array}{l}\text { Overall, I am satisfied with the purchase in this supermarket } \\
\text { The supermarket meets my expectations } \\
\text { The supermarket is close to ideal }\end{array}$ & $\alpha=0.833$ \\
\hline $\begin{array}{l}\text { Customer } \\
\text { loyalty }\end{array}$ & $\begin{array}{l}\text { I intend to continue shopping at this supermarket } \\
\text { I will shop there even if prices rise } \\
\text { In conversations with my friends, I am positive about this supermarket }\end{array}$ & $\omega=0.847$ \\
\hline
\end{tabular}

Source: own elaboration.

Table 2

Sample characteristics

\begin{tabular}{|c|c|c|c|c|}
\hline Feature & & Percent, $\%$ & Supermarkets & Percent, $\%$ \\
\hline Gender & female & 72.9 & Biedronka & 36.0 \\
\hline & male & 27.1 & Lidl & 17.7 \\
\hline Age & no data & 1.2 & Kaufland & 10.1 \\
\hline & less than 18 y.o. & 0.6 & Tesco & 7.3 \\
\hline & $18-25$ & 49.4 & Lewiatan & 5.5 \\
\hline & $25-40$ & 22.3 & Delikatesy Centrum & 3.7 \\
\hline & $40-65$ & 24.7 & Aldi & 3.0 \\
\hline Voivodship & 65 and more & 1.8 & Dino & 3.0 \\
\hline & Silesian & 12.7 & Other & 13.7 \\
\hline
\end{tabular}

Source: own research.

Table 3

Sumptions of the modelling

\begin{tabular}{|l|l|}
\hline Modelling method & Structural equations modelling (SEM) \\
\hline Measuring manifest variables & $\begin{array}{l}\text { Survey research } \\
\text { 5-point Likert scale }\end{array}$ \\
\hline Latent variable blocks & Reflective \\
\hline Verification of the measurement model & $\begin{array}{l}\text { Cronbach's } \alpha \text { coefficient } \\
\text { McDonald's } \omega \text { coefficient }\end{array}$ \\
\hline Estimation & $\begin{array}{l}\text { Maximum likehood method (ML) } \\
\text { Intercept }=0 \text { in inner model equations }\end{array}$ \\
\hline Calculations & lavaan (Rosseel, 2012) in R environment \\
\hline
\end{tabular}

Source: own research. 
Customer satisfaction and retailer image as drivers of customer loyalty: evidences

Results of the modelling are presented in Table 4, 5 and on the Fig. 2.

Table 4

Results of the modelling

\begin{tabular}{|l|l|l|l|l|l|}
\hline \multicolumn{1}{|c|}{ Hypothesis and path } & \multicolumn{1}{|c|}{ Path coefficient } & $\begin{array}{c}\text { Standard } \\
\text { error }\end{array}$ & $\mathrm{z}$ & p-value & \multicolumn{1}{|c|}{ Significance } \\
\hline H1: IMG $\rightarrow$ LOY & 0.306 & 0.089 & 3.440 & 0.001 & $\begin{array}{l}\text { Yes } p<=0.001 \\
\text { H1 supported }\end{array}$ \\
\hline H2: SAT $\rightarrow$ LOY & 0.676 & 0.086 & 7.851 & 0.000 & $\begin{array}{l}\text { Yes } p<=0.001 \\
\text { H2 supported }\end{array}$ \\
\hline H3: IMG $\rightarrow$ SAT & 0.864 & 0.087 & 9.873 & 0.000 & $\begin{array}{l}\text { Yes } p<=0.001 \\
\text { H3 supported }\end{array}$ \\
\hline
\end{tabular}

Source: own research.

Table 5

Model fit measures

\begin{tabular}{|l|l|}
\hline Model fit measure & Value \\
\hline Comparative Fit Index (CFI) & 0.934 \\
\hline Tucker-Lewis Index (TLI) & 0.915 \\
\hline Goodness of Fit Index (GFI) & 0.914 \\
\hline Root Mean Square Error of Approximation (RMSEA) & 0.088 \\
\hline Standardized Root Mean Square Residual (SRMR) & 0.044 \\
\hline
\end{tabular}

Source: own research.

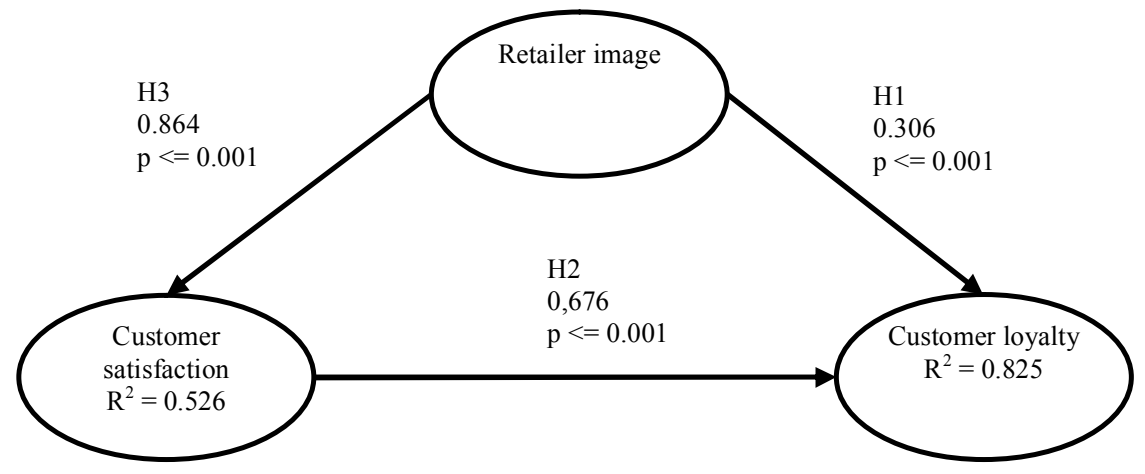

Fig. 2. Model determined in the study

Source: own elaboration.

\section{Conclusions and recommendations for further research}

All relationships included in the model were confirmed at a high significance level ( $\mathrm{p}<=0.001)$. The model fit is at sufficient level (fit indices significantly over 0.8), although RMSEA is slightly about recommended threshold (0.05).

Both construct: retailer image and customer satisfaction have important influence on customer loyalty. But the scale of this impact is different. Calculated path coefficients prove that customer 


\section{G. Biesok}

satisfaction (path coeff. $=0.676$ ) has two times bigger impact on loyalty than retailer image (path coeff. $=$ $=0.306$ ). But considering strong relation between image and customer satisfaction, we have to notice that image also affects to loyalty indirectly (with satisfaction as a mediator). These results are in line with the conclusions reached by Nesset, Nervik \& Helgesen (2011). Their findings state that customer's perception of store assortment only influences perception of image and ultimately loyalty indirectly via satisfaction, whereas price evaluation and service quality works directly both through image building and satisfaction creation. So satisfaction creation seems to be more important for store loyalty than image building.

A useful conclusion of the research is that retailers should focus on building customer satisfaction, as it is the main drive of loyalty. Understanding customer needs and expectations and meeting them should be a priority for managers, because it translates into customer affection and adequate profitability in the long term.

Future research should concentrate on the different types of loyalty and theirs drivers, because there relation are not sufficiently explained in the literature. It is hard to disagree with Clottey at al. (2008) that in the retail industry, customers' brand loyalty often outweighs their store loyalty. Their research showed that brand image was the strongest driver of customer loyalty followed by product quality then service quality. So the relation between brand loyalty and loyalty to the retailer is also an interesting field of research.

1. Anderson, E. W., \& Sullivan, M. W. (1993). The antecedents and consequences of customer satisfaction for firms. Marketing science, 12(2), 125-143.

2. Beneke, J., Adams, E., Demetriou, O., \& Solomons, R. (2011). An exploratory study of the relationship between store image, trust, satisfaction and loyalty in a franchise setting. Southern African Business Review, 15(2), $59-74$.

3. Biesok, G., \& Wyród-Wróbel, J. (2016). Modele satysfakcji klienta. Difin.

4. Biesok, G., \& Wyród-Wróbel, J. (2018). Models of customer satisfaction with supermarkets in Poland. European Journal of Business Science and Technology, 4(1), 81-92. https://doi.org/10.11118/ejobsat.v4i1.113

5. Chen, S. C., \& Quester, P. G. (2006). Modeling store loyalty: perceived value in market orientation practice. Journal of Services Marketing, 20(3), 188-198. https://doi.org/10.1108/08876040610665643

6. Clottey, T. A., Collier, D. A., \& Stodnick, M. (2008). Drivers of customer loyalty in a retail store environment. Journal of Service Science, 1(1), 35-48.

7. Cornelius, B., Natter, M., \& Faure, C. 2010. How storefront displays influence retail store image. Journal of Retailing and Consumer Services, 17(2), 143-151.

8. East, R., Harris, P., Lomax, W., Willson, G., \& Perkins, D. (1997). First-store loyalty to US and British supermarkets. Journal of Marketing Management, 16(4), 307-326.

9. Huddleston, P., Whipple, J., Mattick, R. N., \& Lee, S. J. (2009). Customer satisfaction in food retailing: comparing specialty and conventional grocery stores. International Journal of Retail \& Distribution Management, 37(1), 63-80. https://doi.org/10.1108/09590550910927162

10. Ivanauskienè, N., \& Volungènaitè, J. (2014). Relations between service quality and customer loyalty: An empirical investigation of retail chain stores in emerging markets. American International Journal of Social Science, 3(2), 113-120.

11. Kamran-Disfani, O., Mantrala, M. K., Izquierdo-Yusta, A., \& Martínez-Ruiz, M. P. (2017). The impact of retail store format on the satisfaction-loyalty link: An empirical investigation. Journal of Business Research, 77, 14-22.

12. Koo, D. M. (2003). Inter-relationships among store images, store satisfaction, and store loyalty among Korea discount retail patrons. Asia Pacific Journal of Marketing and Logistics, 15(4), 42-71. https://doi.org/10.1108/13555850310765033

13. Mafini, C., \& Dhurup, M. (2015). Drivers of customer loyalty in South African retail stores. Journal of Applied Business Research (JABR), 31(4), 1295-1310.

14. Miranda, M., Kónya, L. \& Havrila, I. (2005). Shoppers' satisfaction levels are not the only key to store loyalty. Marketing Intelligence \& Planning, 23(2), 220-232. https://doi.org/10.1108/02634500510589958

15. Nesset, E., Nervik, B., \& Helgesen, Ø. (2011). Satisfaction and image as mediators of store loyalty drivers in grocery retailing. The International Review of Retail, Distribution and Consumer Research, 21(3), 267292. https://doi.org/10.1080/09593969.2011.588716 
16. Oliver, R. L. (1999). Whence consumer loyalty?. Journal of Marketing, 63(4), 33-44.

17. $\mathrm{R}$ Core Team (2019). $R$ : A language and environment for statistical computing. $R$ Foundation for Statistical Computing, Vienna, Austria. https://www.R-project.org/

18. Rosseel, Y. (2012). lavaan: An R package for structural equation modeling. Journal of Statistical Software, 48(2), 1-36. http://www.jstatsoft.org/v48/i02/

19. Siddiqi, K. O. (2011). Interrelations between service quality attributes, customer satisfaction and customer loyalty in the retail banking sector in Bangladesh. International Journal of Business and Management, 6(3), 12-36.

20. Stone, M., Bearman, D., Butscher, S. A., Gilbert, D., Crick, P., \& Moffett, T. (2003). The effect of retail customer loyalty schemes - Detailed measurement or transforming marketing?. Journal of Targeting, Measurement and Analysis for Marketing, 12(3), 305-318.

21. Turner, J. J., \& Wilson, K. (2006). Grocery loyalty: Tesco Clubcard and its impact on loyalty. British Food Journal, 108(11), 958-964. https://doi.org/10.1108/00070700610709995

22. Weerasiri, R. A. S. (2015). A study on service quality and customer satisfaction of supermarkets in Sri Lanka. Sri Lanka Journal of Marketing, 1(2), 36-46.

23. Yang, Z., \& Peterson, R. T. (2004). Customer perceived value, satisfaction, and loyalty: The role of switching costs. Psychology \& Marketing, 21(10), 799-822.

24. Zakaria, I., Rahman, B. A., Othman, A. K., Yunus, N. A. M., Dzulkipli, M. R., \& Osman, M. A. F. (2014). The relationship between loyalty program, customer satisfaction and customer loyalty in retail industry: A case study. Procedia-Social and Behavioral Sciences, 129, 23-30.

Г. Бссок

Університет Бельско-Бяла (Польща),, кафедра менеджменту

\section{ЗАДОВОЛЕНІСТЬ СПОЖИВАЧІВ ТА ІМІДЖ ПІДПРИЕМСТВ РОЗДРІБНОЇ ТОРГІВЛІ ЯК ВПЛИВ НА ЛОЯЛЬНІСТЬ КЛІЕНТІВ: ДОКАЗИ ВІД ПОЛЬСЬКИХ СУПЕРМАРКЕТІВ}

(C) Бєсок Г., 2020

Наведено результати досліджень лояльності кліснтів на ринку роздрібної торгівлі. Вивчається ступінь впливу задоволеності споживачів та іміджу підприємств роздрібної торгівлі на лояльність клієнтів. Використано первинні дані опитування, багатоелементні шкали та моделювання структурних рівнянь (SEM). Концептуальна модель, що використовусться у дослідженні, поєднує 3 приховані змінні: імідж продавця, задоволеність клієнтів та лояльність клієнтів. Прихованим змінним відповідає набір проявлених змінних, що були отримані під час опитування. Опитували клієнтів супермаркетів на півдні Польщі. Анкети були поширені за допомогою методу снігової кулі. Загалом у вибірку входили 328 респонденти. Моделювання структурного рівняння підтвердило всі взаємозв'язки в моделі із високим рівнем значущості $(p<=0,001)$. Отже, модель прийнятною. Дослідження показало, що імідж підприємств роздрібної торгівлі та задоволеність споживачів значно впливають на лояльність кліснтів. Важливим висновком є те, що задоволеність кліснтів має вдвічі більший вплив на лояльність, ніж імідж продавця. Отже, роздрібні торгівці повинні зосередити увагу на підвищенні задоволеності кліснтів, оскільки це головний чинник їх лояльності.

Ключові слова: дослідження споживачів, задоволеність споживачів, лояльність кліснтів, супермаркети, роздріб. 